\title{
A Case of Successful Treatment with Trastuzumab for Advanced Salivary Duct Carcinoma in the Accessory Parotid Gland with Multiple Bone Metastasis
}

\author{
Jiro Aoi, Kahori Hirose, Taisuke Kobayashi and Masamitsu Hyodo
}

\begin{abstract}
Salivary duct carcinoma (SDC) is a highly malignant salivary gland tumor. Because of its low incidence, it has been impossible to standardize the optimal treatment strategies for SDC including adjuvant systemic therapy. Recently, it has been reported that SDC resembles mammary ductal carcinoma (DC). Overexpression of human epidermal growth factor type-2 (HER-2) protein has been shown in SDC as in mammary DC. We report herein on a successful treatment experience for a patient with advanced SDC using trastuzumab, a humanized monoclonal antibody.

A 56-year-old male was hospitalized with lumbalgia. Radiological examination indicated a tumor in the right accessory parotid gland and multiple metastatic tumors in the left skull base, ribs, lumbar vertebrae and sacral bone. Incisional biopsy of the right accessory parotid gland revealed SDC. Immunostaining for HER-2 was highly positive. He underwent concurrent radiation- and chemoradiotherapy (intensitymodulated radiotherapy [IMRT $60 \mathrm{~Gy}$ ], nedaplatin and docetaxel), which resulted in a poor response. Thereafter, trastuzumab was administered. He obtained a significantly effective response after 8 courses of treatment for the metastatic lesions.

In contrast to previous reports of a poor response to chemotherapy and poor survival rate of patients with SDC, our patient demonstrated that trastuzumab was a highly effective modality as a therapeutic choice for SDC.
\end{abstract}

Keywords : trastuzumab, salivary duct carcinoma, accessory parotid gland, HER-2 protein

\section{References}

1) Kleinsasser O, Klein HJ and Hübner G : Speichelgangcarcinome. Eine den Milchgangcarcinomen der Brüstdruse analoge Gruppe von Speicheldrüsentumoren. Arch Klin Exp Ohren Nasen Kehlkopfheilkd 192: 100-115, 1968.

2) Slamon DJ, Clark GM, Worg SG, et al. : Human breast cancer: correlation of relapse and survival with amplification of the HER-2/neu oncogene. Science 235: 177-182, 1987.

3) Skálová A, Stárek I, Vanecek T, et al. : Expression of HER-2/ neu gene and protein in salivary duct carcinomas of parotid gland as revealed by fluorescence in-situ hybridization and immunohistochemistry. Histopathology 42: 348-356, 2003.

4) Lewis JE, McKinney BC, Weiland LH, et al. : Salivary duct carcinoma. Clinicopathologic and immunohistochemical review of 26 cases. Cancer 77: 223-230, 1996.

5) Delgado R, Vuitch F and Albores-Saavedra J : Salivary duct carcinoma. Cancer 72: 1503-1512, 1993.
6) Guzzo M, Di Palma S, Grandi C, et al. : Salivary duct carcinoma: clinical characteristics and treatment strategies. Head Neck 19: 126-133, 1997.

7) Jaehne M, Roeser K, Jaekel $\mathrm{T}$, et al. : Clinical and immunohistologic typing of salivary duct carcinoma: a report of 50 cases. Cancer 103: 2526-2533, 2005.

8) Luna MA, Batsakis JG, Ordóñez NG, et al. : Salivary gland adenocarcinomas: a clinicopathologic analysis of three distinctive types. Semin Diagn Pathol 4: 117-135, 1987.

9) Frommer J : The human accessory parotid gland: its incidence, nature, and significance. Oral Surg Oral Med Oral Pathol 43: 671-676, 1977.

10) Stenner M, Preuss SF, Hüttenbrink KB, et al. : Accessory parotid gland lesions: case report and review of literature. Eur Arch Otorhinolaryngol 265: 1135-1138, 2008.

11）高橋光明, 高原 幹, 松井玲子, 他：副耳下腺腫瘍に対す る手術法. 頭頸部外 7: 1-6, 1997.
Department of Otolaryngology, Kochi University, School of Medicine
Corresponding Author Address : Jiro Aoi

aoijiro@kochi-u.ac.jp 
12）篠 美紀, 大氣誠道, 大池信之, 他 : 煩部に発生した粘表 皮癌の 1 症例. 耳鼻・頭頸外科 79: 861-865, 2007.

13) Kurata N, Noguchi Y, Sugimoto T, et al. : Accessory parotid gland pleomorphic adenoma: a case report. Pract Otol (Kyoto) 102: 121-125, 2009.

14) Johnson FE and Spiro RH : Tumors arising in accessory parotid tissue. Am J Surg 138: 576-578, 1979.

15）小野友道, 山本伸二, 荒尾龍喜, 他：唾液腺導管癌一 Comedo Carcinoma一の 1 例. 日皮病理組織会誌 6: 74-77, 1990.

16) Yoshimura K, Imanaka M, Atago T, et al. : Salivary duct carcinoma in the accessory parotid gland; a case report. Pract Otol (Kyoto) 95: 69-74, 2002.

17) 白土秀樹：比較的まれな腫瘍一副耳下腺腫瘍について一. 耳鼻と臨 58: 96-100, 2012.

18）豊岡辰明, 内藤慎二：HER-2 蛋白を発現した唾液導管癌 (Salivary duct carcinoma) の 1 例. 医療 58: 109-113, 2004.

19) Glisson $B$, Colevas AD, Haddad R, et al. : HER2 expression in salivary gland carcinomas: dependence on histological subtype. Clin Cancer Res 10: 944-946, 2004.

20) 鈴木崇祥, 加納里志, 折舘伸彦, 他：唾液導管癌における
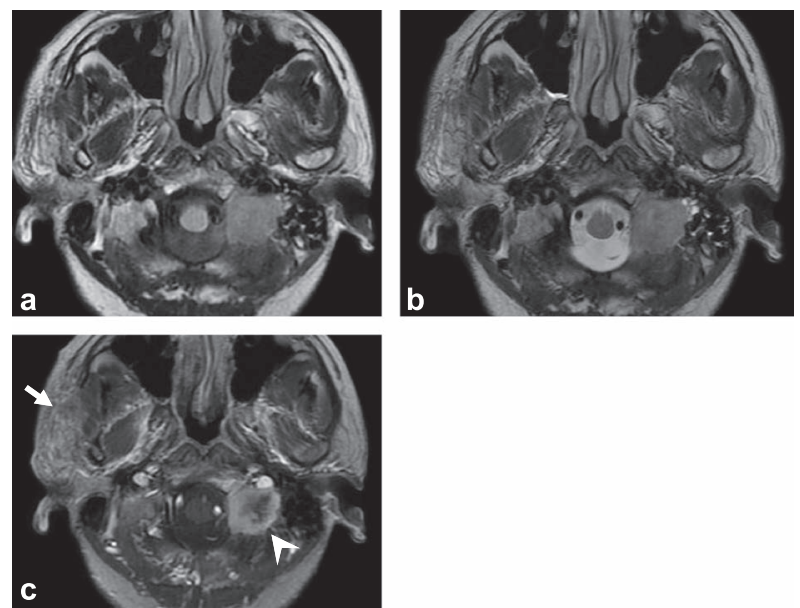

Magnetic resonance imaging (MRI) findings in the head at the first visit

MRI demonstrated a tumor of $18 \mathrm{~mm}$ in diameter in the area anterior to the right ear as well as a tumor of $27 \mathrm{~mm}$ in diameter in the left side of the skull base. Both lesions demonstrated low intensity in T1-weighted images (a), high intensity in T2-weighted images (b), and marginal enhancement in Gd-enhanced T1-weighted images (c).
HER2 の発現解析．頭頸部外 21: 195-201, 2011.

21) Slamon DJ, Leyland-Jones B, Shak S, et al. : Use of chemotherapy plus a monoclonal antibody against HER2 for metastatic breast cancer that overexpresses HER2. N Engl J Med 344: 783-792, 2001.

22) Seidman A, Hudis C, Pierri MK, et al. : Cardiac dysfunction in the trastuzumab clinical trials experience. J Clin Oncol 20: 1215-1221, 2002.

23) Prat A, Parera M, Reyes V, et al. : Successful treatment of pulmonary metastatic salivary ductal carcinoma with trastuzumab-based therapy. Head Neck 30: 680-683, 2008.

24) Kaidar-Person O, Billan S and Kuten A : Targeted therapy with trastuzumab for advanced salivary ductal carcinoma: case report and literature review. Med Oncol 29: 704-706, 2012.

25) Haddad R, Colevas AD, Krane JF, et al. : Herceptin in patients with advanced or metastatic salivary gland carcinomas. A phase II study. Oral Oncol 39: 724-727, 2003.

26) 蓮尾麻里, 南野雅之, 八木正夫, 他：HER-2 蛋白を発現 した Salivary Duct Carcinoma におけるトラスッズマブ使用 の検討． 頭頸部癌 32: 68-71, 2006.

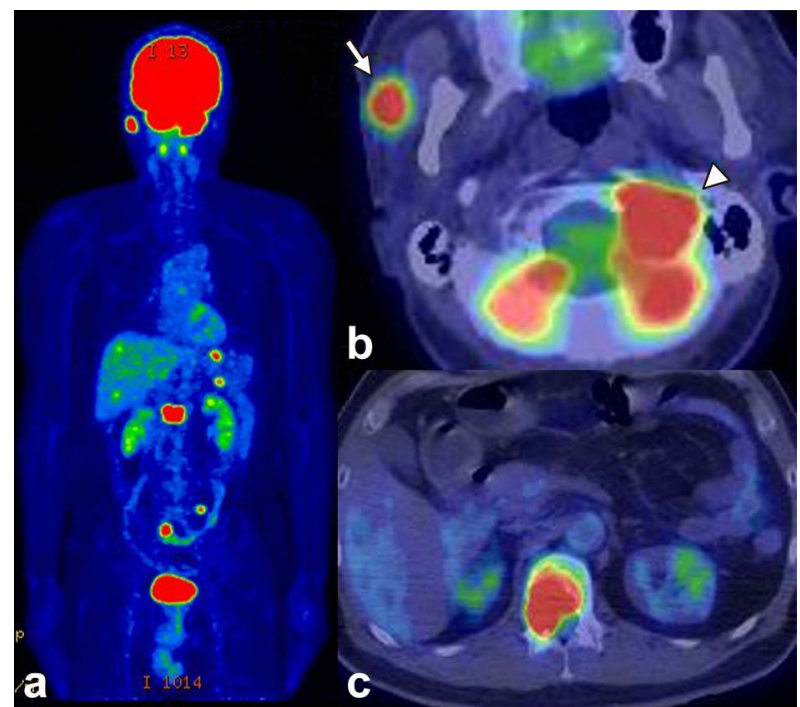

FDG-PET findings at the first visit

FDG accumulation was observed in multiple sites over the whole body (a). Strong accumulation was observed in particular in the area anterior to the right ear (arrow in (b)), the left side of the skull base (arrowhead in (b)), and in the vertebrate body of the first lumbar vertebra (c). 